\title{
Ecology and biogeography in 3D: The case of the Australian Proteaceae
}

\author{
J.G. Pausas \& B.B. Lamont
}

The final version will be published in Journal of Biogeography (2018), https://doi.org/10.1111/jbi.13348

\begin{abstract}
The key biophysical pressures shaping the ecology and evolution of species can be broadly aggregated into three dimensions: environmental conditions, disturbance regimes and biotic interactions. The relative importance of each dimension varies over time and space, and in most cases multiple dimensions need to be addressed to adequately understand the habitat and functional traits of species at broad spatial and phylogenetic scales. However, it is currently common to consider only one or two selective pressures even when studying large clades. We illustrate the importance of the all-inclusive multidimensional approach with reference to the large and iconic plant family, Proteaceae: we review life-history traits related to these three dimensions for the 46 genera occurring in Australia and show that this family can be considered the product of a long history of harsh environments, recurrent fires and strong faunal interactions. Because most Proteaceae species occur in fire-prone ecosystems and possess fire-adaptive traits that are both ancient and essential for their survival, disturbance by fire is likely to explain much of this family's ecology, evolution and distribution. Approaches that only examine prevailing environmental variables may fail to identify the mechanisms that drive a taxon's biogeography; they need to consider the likely mechanisms of adaptation and accept or reject plausible alternative hypotheses as the evidence allows. As multidisciplinary teams that consider all aspects of a taxon's ecology are assembled, and databases and numerical tools become increasingly available, studies on the ecology, biogeography and diversity of organisms at broader spatial and phylogenetic scales will arrive at more realistic conclusions.
\end{abstract}

\section{1 | EVOLUTIONARY DIMENSIONS}

The phenotype and genotype of organisms, and the distribution of taxa across the world, are the product of a long evolutionary history. Over millions of years, plants and animals have been constantly reshaped in response to many evolutionary pressures, and the importance and intensity of each agent of selection has changed over time and across space. From the snapshot we see today, an important objective of biogeography is to identify the key factors explaining how and why biodiversity has arisen on our planet.

Here, we argue that the main evolutionary pressures that shape biodiversity can be aggregated along three axes: environmental conditions (including climate and resources such as soil nutrients and water availability), disturbance regimes and biotic interactions
(Figure 1a). The relative importance of each type of pressure has varied over time and across space (Keeley, Pausas, Rundel, Bond, \& Bradstock, 201 1). For instance, in regions where the climate (e.g. arid or cold ecosystems) or substrate (e.g. wetlands) is relatively extreme, environmental factors (temperature, water availability, salinity) are likely to play a major role in shaping species traits and distributions. Under intermediate and seasonal climatic conditions (e.g. tropical savannas, mediterranean ecosystems), disturbance is likely to play a major role (Bond, Woodward, \& Midgley, 2005; Keeley, Bond, Bradstock, Pausas, \& Rundel, 2012). In contrast, under benign and largely aseasonal conditions (e.g. rain forests), species interactions are predicted to predominate (Galetti et al., 2013). The importance of these different evolutionary pressures changes through time as climate, atmospheric composition, disturbance regime and interacting species have changed throughout the history of the Earth (Barnosky, Koch, Feranec, Wing, \& Shabel, 2004; He \& Lamont, 201 7; Keeley et al., 2012; Pausas \& Keeley, 2009).

Of course, these three dimensions are not always independent; for instance, disturbance regimes may be linked to climate, and thus some plant traits may be correlated. This is the case with fire-prone ecosystems, because they undergo a dry season, many plants in theses ecosystems show important adaptations to drought in addition to adaptations to fire (Lamont \& He, 201 7a; Pausas et al., 2016; Vilagrosa, Hernåndez, Luis, Cochard, \& Pausas, 2014). Furthermore, these evolutionary dimensions may interact. For instance, poor soils may increase plant flammability and frequent fires in turn will further reduce soil fertility (Ojeda, Pausas, \& Verdủ, 2010); or frequent fire may modify biotic interactions and affect the fitness of flammable species (Garcla, Castellanos, \& Pausas, 2016). Despite these correlations and interactions, many plant traits are readily assignable to particular dimensions (Table 1), and for a mechanistic understanding of plant phenotypes and their distribution, it is important to consider the relevance of each of the three dimensions.

However, historically, few studies have dealt with multiple evolutionary dimensions at the same time, in part because they are linked to different approaches and expertise of the various research groups (e.g. ecophysiology, disturbance ecology, reproductive biology). In addition, the lack of suitable data and numerical tools for such multidimensional (multidisciplinary) analyses may have limited the use of this approach. As databases and phylogenetic and numerical tools become increasingly available (Benson, Karsch-Mizrachi, Lipman, Ostell, \& Wheeler, 2005; Kattge et al., 2011; Paradis, 2012; GBIF.org), studies on the ecology, biogeography and diversity of organisms at broader spatial and phylogenetic scales become feasible. 
(a) General

\section{Environment Disturbance}

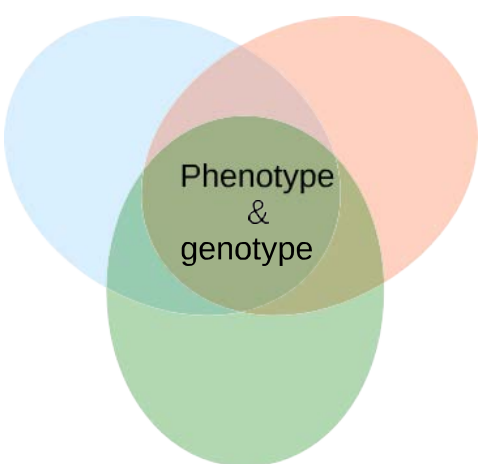

Biotic interactions

\section{(b) Proteaceae}

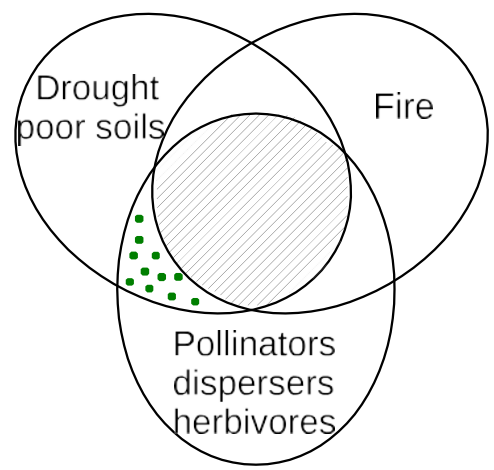

Sclerophyll species

$\because$ Non-fireprone species

FIGURE 1 The evolutionary pressures that shape the phenotype and genotype of an organism can be aggregated into three dimensions (a): environmental factors (e.g. climate, soils, topography), disturbances, and biotic interactions; each of these dimensions is related to a particular set of traits (Table 1). In the case of the Australian Proteaceae (b), the factors determining these three dimensions define the characteristics of most species (sclerophyllous species; Figure 3 right); excluding one dimension (fire) define the few Proteaceae species that occur in non-fireprone ecosystems (Figure 3 left) [Colour figure can be viewed at wileyonlinelibrary.com]

Thus, technology now matches desirability when considering multiple evolutionary dimensions (Araŭjo \& Luoto, 2007; Staniczenko, Sivasubramaniam, Suttle, \& Pearson, 2017).

The interplay between the different evolutionary dimensions can be illustrated by the iconic plant family Proteaceae (Figures $1 \mathrm{~b}$ and 2). With more than 115 million years of history, the Proteaceae has radiated into over 80 genera and 1,700 species essentially distributed in the Southern Hemisphere; its species are especially abundant in Australia and southern Africa, with southwestern Australia as the main diversity hotspot (Cowling \& Lamont, 1998; Figure 3, Table S1). In the following section, we summarize how the three evolutionary dimensions noted above have contributed to the ecology, distribution and diversity of the Proteaceae.

\section{2 | PROTEACEAE IN 3D}

\section{1 | Environment}

The Proteaceae is well-known for its production of "proteoid" roots, specialized root clusters for enhancing nutrient uptake that occur in most species of the family (Figure 4). These roots exude organic acids that increase phosphorus-uptake efficiency as an alternative pathway to mycorrhizal symbioses for survival in nutrient-impoverished soils. Many Proteaceae also have highly scleromorphic leaves, and include species regarded among the world's most sclerophyllous (Lamont, Hanley, Groom, \& He, 2016; Lamont, He, \& Lim, 2016); these traits are considered a response to both infertile soils (high leaf density) and drought (high leaf thickness) (Lamont, Groom, Williams, \& He, 2015). These features contrast with the basal, bifacial meso-macrophylls associated with the rain forest taxa (Flora of Australia 1995).

\section{2 | Disturbance}

Another well-known feature of the Proteaceae is the prevalence of serotiny (on-plant seed storage), a clear adaptation to recurrent crown fire (Keeley et al., 2011; Lamont \& Enright, 2000). Where resources for seed production are limited, accumulation of seeds in the crown enables the critical number for self-replacement to be reached following disturbance. Fire is both the cue for seed release and the cause of ideal recruitment conditions. No other family has so many serotinous species and the diversity of serotinous structures is without peer; it is especially common among the most species-rich genera (Figure 4). Recent studies show that serotiny is an ancestral trait that arose during the fiery Cretaceous (Lamont \& He, 2012). Less well-known, but also common among Proteaceae, is the presence of a soil seed bank with fire-stimulated (heat and smoke-cued) germination (Figure 4). Again germination is cued to the period when recruitment is most likely to be successful (interfire establishment makes a negligible contribution to population dynamics).

The Proteaceae also includes other fire adaptations such as species with enhanced flammability around the serotinous cones and retention of dead foliage that ensure seed release (He, Lamont, \& Downes, 2011; Table S1), some with thick bark and epicormic resprouting that enable trees to survive fire (Groom \& Lamont, 2015), and many with large belowground bud banks located in lignotubers, root crowns or woody rhizomes that enable shrubs to recover from fire (Cowling \& Lamont, 1998; Myerscough, Whelan, \& 


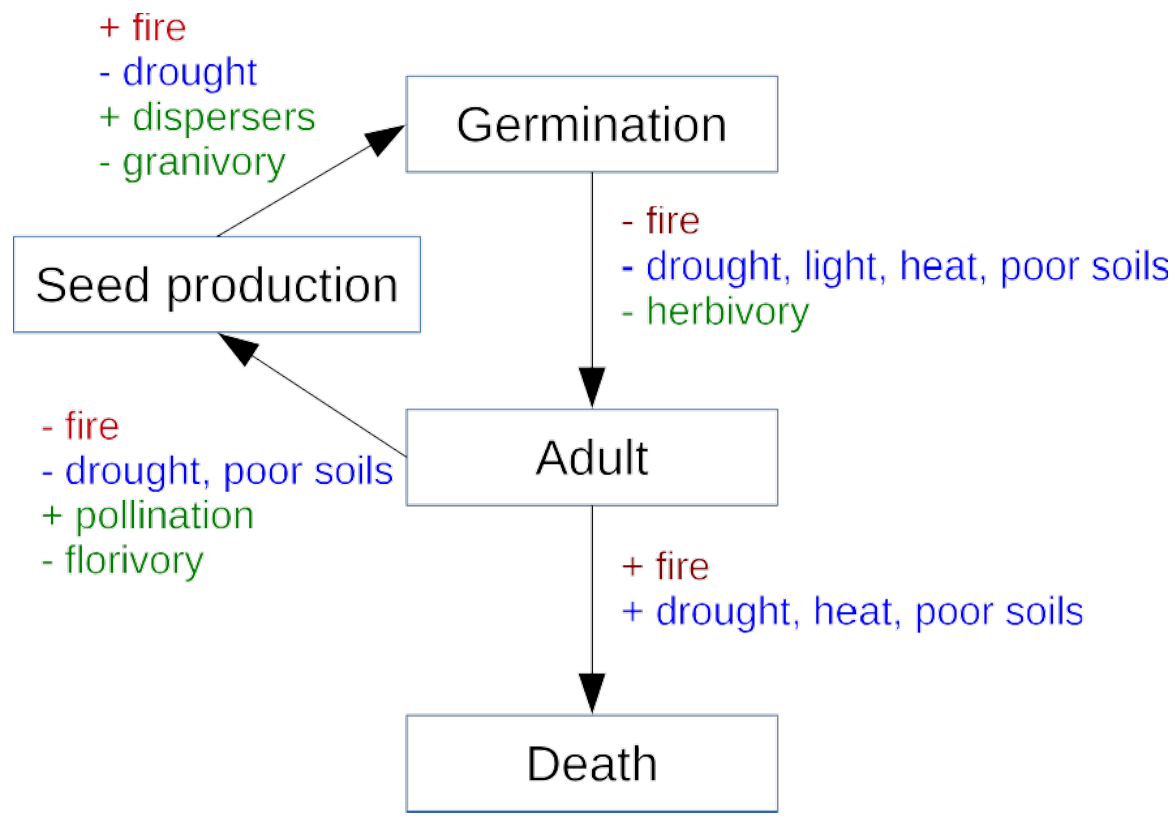

FIGURE 2 The way different ecological drivers promote (+) or retard (-) the life cycle of most Proteaceae species. Note that fire is a vital factor in their successful reproduction (fire stimulates seed release and dispersal or germination; Figure 4) [Colour figure can be viewed at wileyonlinelibrary.com]

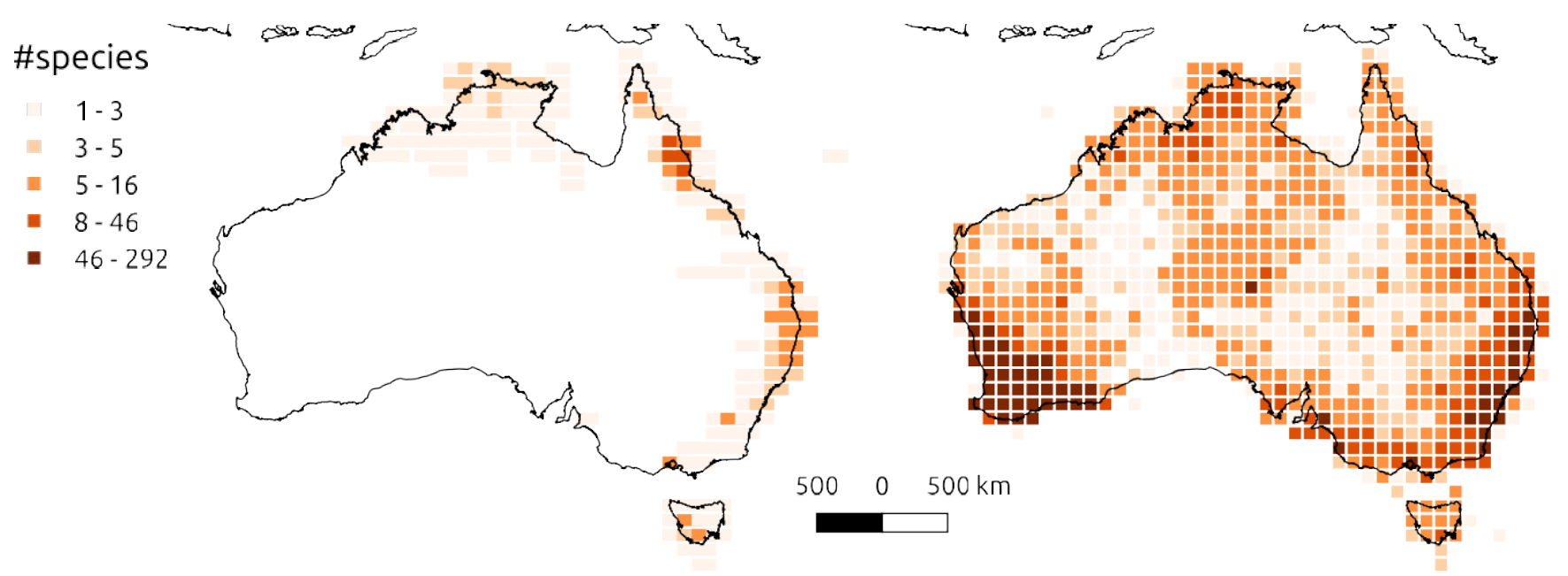

FIGURE 3 Proteaceae species richness in Australia by cells of 1 degree. Left: genera in non-fire-prone vegetation (rain forest and vine forest). Right: genera in fire-prone vegetation (savanna grassland and sclerophyll shrubland, woodland and forest). Note the concentration of records in SW and lesser extent SE Australia. Prepared from 218.322 records obtained from the Global Biodiversity Information Facility (gbif.org; accessed 16 May 2017, https://doi.org/10.15468/dl.9a0rtx). The continent is 3,500 km at its widest [Colour figure can be viewed at wileyonlinelibrary.com]

Bradstock, 2000; Pausas, Lamont, Paula, Appezzato-da-Gloria, \& Fidelis, 2018). None of these fire-related traits are ancestral for the family but each appeared in specific lineages and at different times in response to changing fire regimes (Lamont \& He, 2012; Lamont, He, \& Downes, 2013; Pausas et al., 2018).

\section{3 | Bioticinteractions}

Many Proteaceae species are renowned for their conspicuous inflorescences that are pollinated by a wide range of day- and nightactive insects, but also, more notably and recently in evolutionary time, by marsupials and nectar-feeding birds (Figure 4; Myerscough et al., 2000); some genera, e.g. Telopea, have become solely bird-pollinated. Seed dispersers and granivores are also diverse, from ants to strong-billed cockatoos, emus and other vertebrates (Figure 4; Hanley, Lamont, \& Armbruster, 2009; Lamont, He, et al., 2016; Lamont, Hanley, et al., 2016). The Proteaceae also includes many wind-dispersed species, universally so among serotinous species (Figure 4).

Thus, the wealth of knowledge about the natural history of the Proteaceae suggests that demographic processes (Figure 2 ) and the diversification of this family have been promoted by a long history of harsh environments, recurrent disturbances and a plethora of 


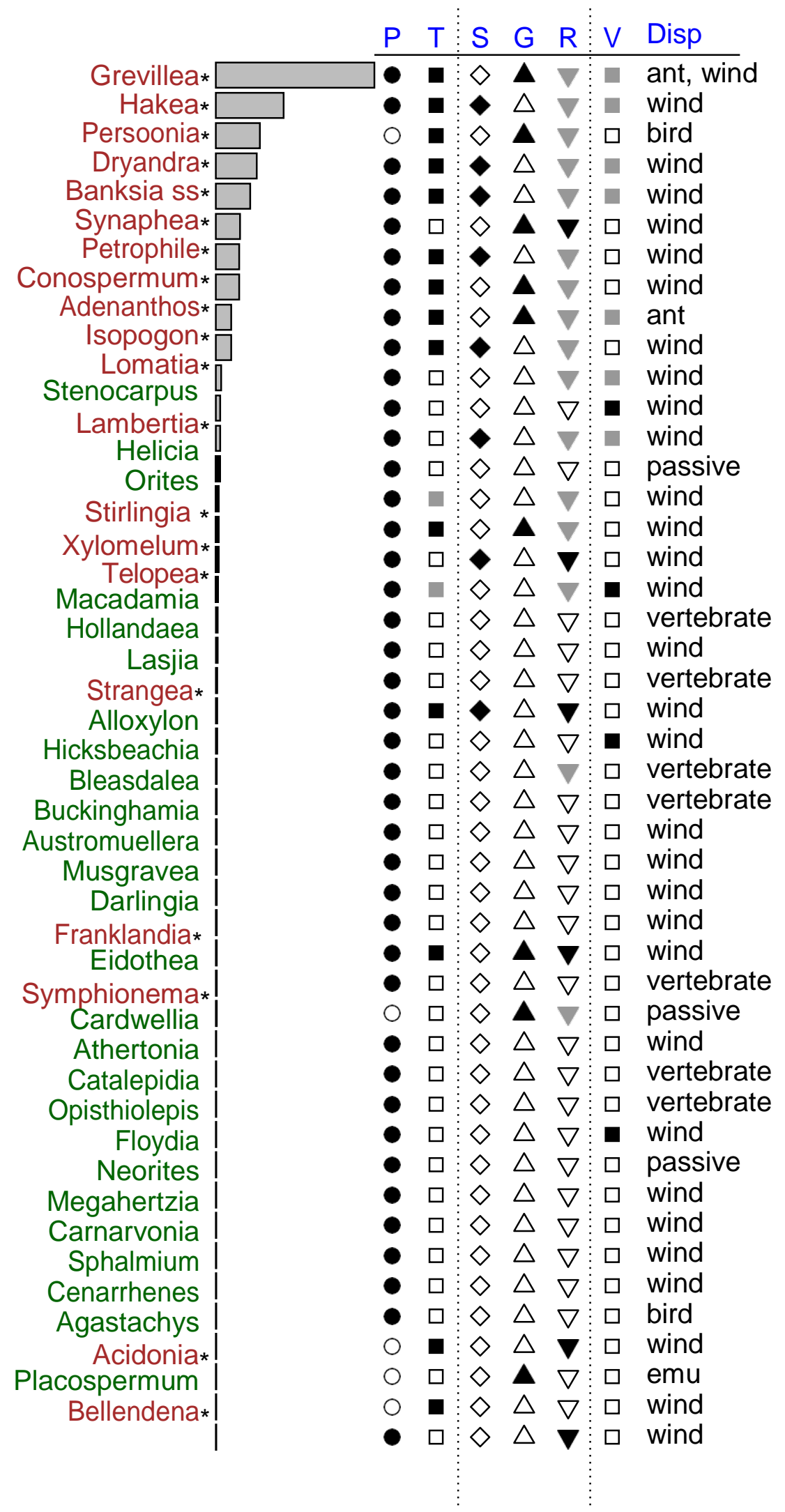

FIGU RE 4 Summary of traits associated with environment, disturbance and biotic interactions, for all Proteaceae genera in Australia. Genera with an asterisk (text in reddish) occur in sclerophyll vegetation, otherwise (text in green) in rain forests. Histogram indicates the number of species (maximum $=360$ in Grevillea). Variables are: presence of proteoid roots (P), thick leaves (including ericoid leaves; T), serotiny (S), fire-stimulated germination $(\mathrm{G})$, resprouting $(\mathrm{R})$, vertebrate pollination $(\mathrm{V})$ and main dispersal vector (Disp). Black symbols = yes (most species); grey symbols = some species; white symbols = no (orrarely). Formoredetails, seeTableS1 [Colourfigure can beviewed atwileyonlinelibrary.com] 
interactions with fauna. Key remaining questions include estimating the time of origin of each adaptation in relation to the temporal order of inauguration of the different evolutionary pressures (Lamont, He, \& Pausas, 2017). Current evidence indicates that many fire-related traits in the Proteaceae originated during the high oxygen atmosphere of the fiery Cretaceous (Carpenter, Holman, Abell, \& Grice, 2016; Lamont \& He, 2017b), and seasonality (and droughtresistance traits) came much later (Lamont $\& \mathrm{He}, 2017 \mathrm{a}$ ). Once the fire-adapted trait evolved, it set the stage for the diversification of the lineage in the presence of the vast range of habitats with different fire ages and fire regimes now available to it. Then, the lineage could respond positively to the appearance of other agents of selection, such as changing climates, advent of new types of pollinators (birds) and herbivores (cockatoos), and further changes in the fire regime. However, the extent of phenotypic and genotypic variability explained by each constraint remains to be studied in detail.

Another topic for further research is the interactions between these pressures, as they do not act in isolation. For instance, the instigation of bird pollination (exposed inflorescences) among Hakea species left the subsequent fruits vulnerable to granivorous insects and birds (especially black cockatoos). Spiny foliage and cryptic fruits that can be employed against granivores by insect-pollinated species (with hidden flowers and fruits) cannot be used by the exposed fruits of bird-pollinated species. As serotiny is of general benefit among hakeas in their nutrient-poor soils (Keeley et al., 2011), the adaptive solution is to produce exceptionally large woody fruits that far exceed their initial role in insulating the seeds against fire heat but now also deter cockatoos from reaching the protein-rich seeds (Lamont, He, et al., 2016; Lamont, Hanley, et al., 2016).

Recently, Onstein et al. (2016) reported on the causes of diversification in the Proteaceae using cutting-edge phylogenetic methods. They concluded that radiations in this family were associated with just one of the three possible dimensions, the seasonal climate of open mediterranean-type vegetation. Similarly, Prentice et al. (2017) explained the spatial distribution of Proteaceae in Australia as a function of the prevailing environment, climate and soils, and Mitchell, Carlson, and Holsinger (2018) only considered climatic parameters in searching for the drivers of Protea radiation in the Cape Floristic Region. Given that the vast majority of Proteaceae lives in fire-prone ecosystems ( $>90 \%$ of the Australian species, Figure 4), and many of them have fire-related traits (Figures 3 and 4, Table S1), it is difficult to understand the life cycle of most Proteaceae without also considering the role of fire (Figure 2). As both Australia and the Cape Region are among the most flammable regions on Earth, and have a long history of recurrent fires (Lamont \& He, 2012; Lamont et al., 2017), one might question to what extent these studies have missed one of the key evolutionary dimensions, disturbance by fire.

Instead, Onstein et al. (2016) used "open" versus "closed" vegetation as a species trait, and found an increase in diversification rate of lineages with small, sclerophyllous leaves in open vegetation, under seasonally dry/warm climates. In fact, fire-prone Proteaceae occur in both dense shrublands and in the understorey of eucalypt forests (Australia's Virtual Herbarium, https://avh.chah.org.au), and in both cases, light is strongly reduced at ground level. These sclerophyll vegetation types are often limited by recruitment, and recurrent fires open the vegetation and select for species with traits for quick recruitment under open post-fire conditions; having a persistent seed bank (in the soil or crown) enables such a strategy to be effective among most Proteaceae (Figure 4). Furthermore, the ancestral reconstruction of the trait "open shrubland" by Onstein et al. (2016) suggests that it appeared in the Cretaceous, but this matches better with the age of fire as a selective process than with the likely Neogene age of the highly seasonal conditions that they considered responsible for scleromorphic leaves (Carpenter et al., 2016; Lamont $\& \mathrm{He}, 2012,2017 \mathrm{a})$.

In addition, geographical variability in climate seasonality is strongly linked to variability in the fire regime, and thus some distribution patterns apparently due to climate could in fact be driven by fire. By looking at plant traits, it is possible to disentangle whether fire or seasonality is the actual constraint shaping those species; serotiny and fire-stimulated germination are good indicators of the former. Thus, traits related to the environment and traits related to fire explain similar levels of deviance in accounting for the number of Proteaceae species per genus, such that a model including both traits makes little further improvement to explaining variance (Figure 5), suggesting that they are strongly correlated. Overall, we suggest that fire is the most likely mechanism behind the pattern observed by Onstein et al. (2016) and Prentice et al. (2017).

There are numerous independent sources of evidence for the long history of fire in Australia, including phylogenetic studies (Crisp,

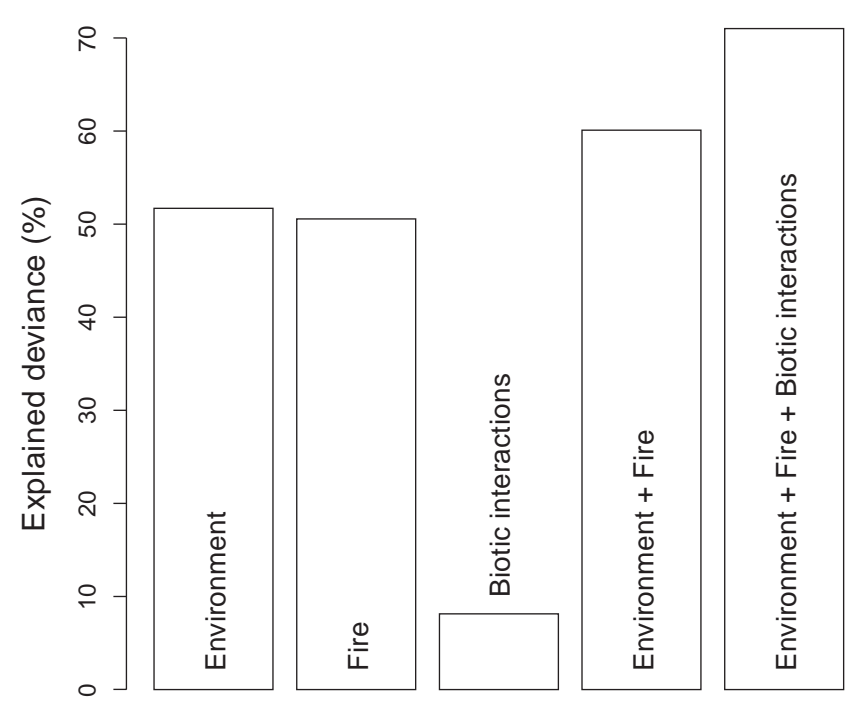

FIGURE 5 Proportion of deviance in species richness pergenus of the Proteaceae listed in Figure 3 and Table $\mathrm{S} 1$ explained by five models combining the different dimensions: Environment only (proteoid roots + thick leaves), fire only (serotiny + fire-stimulated germination), biotic interactions only (vertebrate pollination + animal dispersal), environment + fire and all three dimensions. Models were fitted with a GLM and a quasipoisson link function, using binary traits from Figure 3 (most species versus few or none) 
TABLE 1 Main plant traits that are under selection by the three types of evolutionary pressures

\begin{tabular}{|c|c|c|}
\hline Environment & Disturbance & Biotic interactions \\
\hline $\begin{array}{l}\text { Leaf traits (photosynthetic and water-use efficiency, } \\
\text { heat load control) }\end{array}$ & Bud bank size, location and protection & Flower traits and pollination syndrome \\
\hline Root system traits (spread and depth) & Resource storage (resprouting) & $\begin{array}{l}\text { Fruit and seed traits, seed protection and } \\
\text { dispersal syndrome }\end{array}$ \\
\hline $\begin{array}{l}\text { Nutrient-uptake strategies (fine root development } \\
\text { and location) }\end{array}$ & Seed release and germination cues & Leaf traits (herbivory resistance) \\
\hline $\begin{array}{l}\text { Seed traits (including dormancy and germination, } \\
\text { nutrient storage) }\end{array}$ & Stem protection (bark thickness) & Volatile organic compounds \\
\hline Root:shoot ratio & Root:shoot ratio & Spinescence \\
\hline Leaf area:sapwood area & Volatile organic compounds (flammability) & Stem and root traits (parasitism resistance) \\
\hline \multirow[t]{4}{*}{ Leaf and flowering phenology } & Age to maturity, plant longevity & \multirow{4}{*}{$\begin{array}{l}\text { Nutrient uptake symbioses with } \\
\text { microorganisms }\end{array}$} \\
\hline & Flowering phenology (post-disturbance) & \\
\hline & $\begin{array}{l}\text { Fruit/infructescence traits (seed release } \\
\text { cue, flammability) }\end{array}$ & \\
\hline & $\begin{array}{l}\text { Branching pattern, dead foliage retention } \\
\text { (flammability) }\end{array}$ & \\
\hline
\end{tabular}

Burrows, Cook, Thornhill, \& Bowman, 2011; He et al., 2011; Rundel et al., 2016) and fossil records (Carpenter, Macphail, Jordan, \& Hill, 2015; Macphail \& Stone, 2004; Pole \& Douglas, 1999). These suggest that fire was sufficiently frequent and predictable to act as a selective agent by the mid-upper Cretaceous, essentially due to the high atmospheric oxygen levels in that period; seasonality (summer drought) is a more recent Neogene phenomenon (Lamont \& He, 2012, 2017a). Thus, the diversification and distribution of Proteaceae are likely to be strongly linked to the long history of fire in its habitats, not just by the climate and soil characteristics. In the next section, we specifically show how fire may have driven this diversification.

\section{3 | FIRE AND DIVERSIFICATION}

Post-fire seeders delay their recruitment to the optimal conditions available post-fire. Many Proteaceae produce a persistent seed bank either in the canopy (serotiny) or in the soil, and fire stimulates seed release (in the former) or germination (in the latter) (Figure 4). Wells (1969) suggested that because seeders in fire-prone ecosystems have a high population turnover (recruiting after each fire), they have an increasing opportunity for natural selection to act, compared with species that do not recruit post-fire. Among seeders, recurrent postfire recruitment events increases recombination-based mutations, but also, the fluctuations in population size under recurrent fire favour genetic drift processes (Engen, Lande, \& Saether, 2005). In addition, the fact that seeders recruit from a multiaged seed bank promotes the generation of genetic novelty (Barrett, He, Lamont, \& Krauss, 2005; Levin, 1990). These genetic effects are even stronger in obligate (non-resprouting, fire-killed) seeders as there is no overlap among generations (monopyric life cycle; Pausas \& Keeley, 2014), so enhancing genetic differentiation and evolutionary changes among populations (Ellner \& Hairston, 1994; Wade \& McCauley,
1988). In addition, resprouters under recurrent fire and with large bud banks can also acquire genetic novelty through occasional somatic mutations (Lamont \& Wiens, 2003) whose expression is promoted by fire through the production of new genetically altered seed-bearing stems (Lamont, Enright, \& He, 2011). Furthermore, fire may also promote hybridization (Ortego, Gugger, \& Sork, 2017). Attempts to quantify the relative diversification rates of seeders versus resprouters showed inconclusive results when resprouters were also facultative seeders (Litsios et al., 2014; Verdủ, Pausas, SegarraMoragues, \& Ojeda, 2007), as post-fire seeding is likely a key trait for diversification. However, there is evidence of higher speciation rates among lineages associated with the seeder life history than those lineages associated with obligate resprouting (López-Villalta, 2014; Verdũ \& Pausas, 2013).

All genetic changes associated with the life history of species living in fire-prone ecosystems are the raw material for natural selection to act, and should enable the species to better fill new niches due to changes in the environment, the disturbance regime and the biotic interactions (Schwilk \& Kerr, 2002), with consequent enhanced diversification. There is evidence that populations of the same species living under different fire regimes may diverge phenotypically and genetically (Pausas et al. 2012; Moreira, Castellanos, \& Pausas, 2014; Pausas, 2015; Vandvik et al., 2014). As a consequence of all these processes, the richness of many fire-prone ecosystems can be explained by the high diversification rates associated with fire (Barraclough, 2006; Cowling \& Pressey, 2001; Wisheu, Rosenzweig, Olsvig-Whittaker, \& Shmida, 2000), and Proteaceae is a good example, as all the most species-rich genera ( $>35$ species) are in fire-prone habitats (Figure 4). Overall, fire can be considered a strong driver of differentiation through promoting novelty, selection and stabilization processes (Lamont et al., 2013; He \& Lamont 2018), and thus fire makes a major contribution to global plant diversity (Pausas \& Ribeiro, 2017). 


\section{4 | CONCLUDING REMARKS}

As the scope of ecological and biogeographical studies increases, it becomes more important to include multiple evolutionary dimensions in our analyses. Failure to recognize the prominent ecological and evolutionary roles of fire in fire-prone ecosystems ("fire blindness") is likely to result in a misunderstanding of the key evolutionary processes behind the ecological patterns. To make satisfactory progress in ecology and biogeography, we need to overcome the traditional view that vegetation patterns may be explained solely through climate and soils, and to acknowledge fire as a potent evolutionary force (Keeley et al., 2011; Lamont \& He, 2017b; He \& Lamont 2018) and a key factor in explaining the distribution and diversity of many ecosystems (Bond et al., 2005; He \& Lamont, 2017; Keeley et al., 2012; Pausas \& Keeley, 2009; Pausas \& Ribeiro, 2017). This may be especially important in lineages from mid and low latitude environments where benign climatic conditions for plant growth and fuel build-up alternate with dry periods prone to fire that resets community dynamics. Specifically, Proteaceae without fire (Mitchell et al., 2018; Onstein et al., 2016; Prentice et al., 2017) would still be confined to the rain forest fringes (Figure 3 ) and depauperate in species instead of the dominant position it currently occupies throughout the Australian continent (Figure 4).

We live in a multidimensional world; failing to recognize the different dimensions leads to a biased view of nature. Ecological and biogeographical studies in fire-prone and seasonal ecosystems that focus on environmental correlates should also consider the evidence for plausible alternative hypotheses and possible mechanisms of adaptation.

\section{ACKNOWLEDGEMENTS}

This work was performed under the framework of the FILAS project (CGL2015-64086-P) from the Spanish Government and the PROMETEO/2016/021 project from Generalitat Valenciana. The authors declare no conflicts of interest.

\section{Keywords}

Australia, disturbance regimes, evolutionary pressures, fire ecology, plant traits, Proteaceae

\section{ORCID}

Juli G. Pausas http://orcid.org/0000-0003-3533-5786

Byron B. Lamont http://orcid.org/0000-0001-9279-7149

Juli G. Pausas ${ }^{1}$

Byron B. Lamont ${ }^{2}$

${ }^{1}$ CIDE-CSIC, Montcada, Valencia, Spain

${ }^{2}$ Department of Environment and Agriculture, Curtin University, Perth, WA, Australia
Correspondence

Juli G. Pausas, CIDE-CSIC, Ctra. Naquera km 4.5, 46113 Montcada,

Valencia, Spain.

Email:

juli.g.pausas@ext.uv.es

\section{REF E RE NCE S}

Araújo, M. B., \& Luoto, M. (2007). The importance of biotic interactions for modelling species distributions under climate change. Global Ecology and Biogeography, 16, 743-753. https://doi.org/10.1111/j.14668238.2007.00359.x

Barnosky, A. D., Koch, P. L., Feranec, R. S., Wing, S. L., \& Shabel, A. B. (2004). Assessing the causes of late Pleistocene extinctions on the continents. Science, 306, 70-75. https://doi.org/10.1126/science. 1101476

Barraclough, T. G. (2006). What can phylogenetics tell us about speciation in the Cape flora? Diversity and Distributions, 12, 21-26. https://doi.org/10.1111/j.1366-9516.2006.00208.x

Barrett, L. G., He, T. H., Lamont, B. B., \& Krauss, S. L. (2005). Temporal patterns of genetic variation across a 9-year-old aerial seed bank of the shrub Banksia hookeriana (Proteaceae). Molecular Ecology, 14, 4169-4179. https://doi.org/10.1111/j.1365-294X.2005. 02726.x

Benson, D. A., Karsch-Mizrachi, I., Lipman, D. J., Ostell, J., \& Wheeler, D. L. (2005). GenBank. Nucleic Acids Research, 33, D34-D38.

Bond, W. J., Woodward, F. I., \& Midgley, G. F. (2005). The global distribution of ecosystems in a world without fire. New Phytologist, 165, 525-538.

Carpenter, R. J., Holman, A. I., Abell, A. D., \& Grice, K. (2016). Cretaceous fire in Australia: A review with new geochemical evidence, and relevance to the rise of the angiosperms. Australian Journal of Botany, 64, 564-578. https://doi.org/10.1071/BT16109

Carpenter, R.J., Macphail, M. K., Jordan, G.J., \& Hill, R. S. (2015). Fossil evidence for open, Proteaceae-dominated heathlands and fire in the Late Cretaceous of Australia. American Journal of Botany, 102, 20922107. https://doi.org/10.3732/ajb.1500343

Cowling, R. M., \& Lamont, B. B. (1998). On the nature of Gondwanan species flocks: Diversity of Proteaceae in Mediterranean south-western Australia and South Africa. Australian Journal of Botany, 46, 335355. https://doi.org/10.1071/BT97040

Cowling, R. M., \& Pressey, R. M. (2001). Rapid plant diversification: Planning for an evolutionary future. Proceedings of the National Academy of Sciences, USA, 98, 5452-5457. https://doi.org/10.1073/pnas. 101093498

Crisp, M. D., Burrows, G. E., Cook, L. G., Thornhill, A. H., \& Bowman, D. M. J.S. (201 1). Flammable biomes dominated by eucalypts originated at the Cretaceous-Palaeogene boundary. Nature Communications, 2, 193. https://doi.org/10.1038/ncomms 1191

Ellner, S., \& Hairston, N. G. (1994). Role of overlapping generations in maintaining genetic-variation in a fluctuating environment. American Naturalist, 143, 403-417. https://doi.org/10.1086/285610

Engen, S., Lande, R., \& Saether, B. E. (2005). Effective size of a fluctuating age-structured population. Genetics, 170, 941. https://doi.org/10. 1534/genetics.104.028233

Flora of Australia (1995). Vol 16, Elaeagnaceae, Proteaceae 1. Melbourne, Australia: CSIRO.

Galetti, M., Guevara, R., Cortes, M. C., Fadini, R., Von Matter, S., Leite, A. B., ... Jordano, P. (2013). Functional extinction of birds drives rapid evolutionary changes in seed size. Science, 340, 1086-1090. https://doi.org/10.1126/science.1233774

Garcla, Y., Castellanos, M. C., \& Pausas, J. G. (2016). Fires can benefit plants by disrupting antagonistic interactions. Oecologia, 182, $1165-$ 1173. https://doi.org/10.1007/s00442-016-3733-z 
Groom, P. K., \& Lamont, B. B. (2015). Plant life of Southwestern Australia: Adaptations for survival. Warsaw: De Gruyter Open. https://doi.org/ $10.1515 / 9783110370195$

Hanley, M. E., Lamont, B. B., \& Armbruster, W. S. (2009). Pollination and plant defence traits co-vary in Western Australian Hakeas. New Phytologist, 182, 251-260. https://doi.org/10.1111/j.1469-8137.2008. 02709.x

He, T., \& Lamont, B. B. (2017). Baptism by fire: The pivotal role of ancient conflagrations in evolution of the Earth's flora. National Science Review, 5, 237-254 https://doi.org/10.1093/nsr/nwx041

He, T., \& Lamont, B. B. (2018). Fire as a potent mutagenic agent among plants. Critical Reviews in Plant Sciences, https://doi.org/10.1080/ 07352689.2018 .1453981

He, T., Lamont, B. B., \& Downes, K. S. (2011). Banksia born to burn. New Phytologist, 191, 184-196. https://doi.org/10.1111/j.1469-8137. $2011.03663 . x$

Kattge, J., Diaz, S., Lavorel, S., Prentice, I. C., Leadley, P., \& B6nisch, G., ... Wirth, C. (2011). TRY - a global database of plant traits. Global Change Biology, 17, 2905-2935. https://doi.org/10.1111/j.13652486.2011.02451.x

Keeley, J. E., Bond, W. J., Bradstock, R. A., Pausas, J. G., \& Rundel, P. W. (2012). Fire in Mediterranean ecosystems: Ecology, evolution and management. Cambridge: Cambridge University Press.

Keeley, J. E., Pausas, J. G., Rundel, P. W., Bond, W. J., \& Bradstock, R. A. (2011). Fire as an evolutionary pressure shaping plant traits. Trends in Plant Science, 16, 406-411. https://doi.org/10.1016/j.tplants.2011. 04.002

Lamont, B. B., \& Enright, N. J. (2000). Adaptive advantages of aerial seed banks. Plant Species Biology, 15, 157-166. https://doi.org/10.1046/j. 1442-1984.2000.00036.x

Lamont, B. B., Enright, N. J., \& He, T. (2011). Fitness and evolution of resprouters in relation to fire. Plant Ecology, 2012, 1945-1957. https://doi.org/10.1007/s $11258-011-9982-3$

Lamont, B. B., Groom, P. K., Williams, M., \& He, T. (2015). LMA, density and thickness: Recognizing different leaf shapes and correcting for their non-laminarity. New Phytologist, 207, 942-947. https://doi.org/ $10.1111 / \mathrm{nph} .13465$

Lamont, B. B., Hanley, M. E., Groom, P. K., \& He, T. (2016). Bird pollinators, seed storage and cockatoo granivores explain large woody fruits as best seed defense in Hakea. Perspectives in Plant Ecology, Evolution and Systematics, 21, 55-77. https://doi.org/10.1016/j.ppees.2016.05.002

Lamont, B. B., \& He, T. (2012). Fire-adapted Gondwanan Angiosperm floras evolved in the Cretaceous. BMC Evolutionary Biology, 12, 223. https://doi.org/10.1186/1471-2148-12-223

Lamont, B. B., \& He, T. (2017a). When did a Mediterranean-type climate originate in southwestern Australia? Global and Planetary Change, 156, 46-58. https://doi.org/10.1016/j.gloplacha.2017.08.004

Lamont, B. B., \& He, T. (201 7b). Fire-proneness as a prerequisite for the evolution of fire-adapted traits. Trends in Plant Science, 22, 278-288. https://doi.org/10.1016/j.tplants.2016.11.004

Lamont, B. B., He, T., \& Downes, K. (2013). Adaptive responses to directional trait selection in the Miocene enabled Cape proteas to colonize the savanna grasslands. Evolutionary Ecology, 27, 1099-1115. https://doi.org/10.1007/s10682-013-9645-z

Lamont, B. B., He, T., \& Lim, S. L. (2016). Hakea, the world's most sclerophyllous genus, arose in southwestern Australian heathland and diversified throughout Australia over the past 12 million years. Australian Journal of Botany, 64, 77-88. https://doi.org/10.1071/ BT15134

Lamont, B. B., He, T., \& Pausas, J. G. (2017). South African geoxyles evolved in response to fire; frost came later. Evolutionary Ecology, 31, 306-617.

Lamont, B. B., \& Wiens, D. (2003). Are seed set and speciation rates always low among species that resprout after fire, and why? Evolutionary Ecology, 17, 277-292. https://doi.org/10.1023/A:1025535223021
Levin, D. A. (1990). The seed bank as a source of genetic novelty in plants. American Naturalist, 135, 563-572. https://doi.org/10.1086/285062

Litsios, G., WGiest, R. O., Kostikova, A., Forest, F., Lexer, C., Linder, H. P., ... Salamin, N. (2014). Effects of a fire response trait on diversification in replicated radiations. Evolution, 68, 453-465. https://doi.org/ 10.1111 /evo.12273

Lopez-Villalta, J. S. (2014). Trait-driven vs. syndrome-driven diversification in the Mediterranean woody flora. Ecologia Mediterranea, 40, 27-34.

Macphail, M. K., \& Stone, M. S. (2004). Age and palaeoenvironmental constraints on the genesis of the Yandi channel iron deposits, MarilIana Formation, Pilbara, northwestern Australia*. Australian Journal of Earth Sciences, 51, 497-520. https://doi.org/10.1111/j.1400-0952. 2004.01071.x

Mitchell, N., Carlson, J. E., \& Holsinger, K. E. (2018). Correlated evolution between climate and suites of traits along a fast-slow continuum in the radiation of Protea. Ecology and Evolution, 8, 1853-1866. https://doi.org/10.1002/ece3.3773

Moreira, B., Castellanos, M. C., \& Pausas, J. G. (2014). Genetic component of flammability variation in a Mediterranean shrub. Molecular Ecology, 23, 1213-1223. https://doi.org/10.1111/mec.12665

Myerscough, P. J., Whelan, R. J., \& Bradstock, R. A. (2000). Ecology of Proteaceae with special reference to the Sydney region. Cunninghamia, 6, 951-1015.

Ojeda, F., Pausas, J., \& Verdü, M. (2010). Soil shapes community structure through fire. Oecologia, 163, 729-735. https://doi.org/10.1007/ s00442-009-1550-3

Onstein, R. E., Jordan, G. J., Sauquet, H., Weston, P. H., Bouchenak-Khelladi, Y., Carpenter, R. J., \& Linder, H. P. (2016). Evolutionary radiations of Proteaceae are triggered by the interaction between traits and climates in open habitats. Global Ecology and Biogeography, 25, 1239-1251. https://doi.org/10.1111/geb.12481

Ortego, J., Gugger, P. F., \& Sork, V. L. (2017). Impacts of human-induced environmental disturbances on hybridization between two ecologically differentiated Californian oak species. New Phytologist, 213, 942-955. https://doi.org/10.1111/nph.14182

Paradis, E. (2012). Analysis of phylogenetics and evolution with $R$, 2nd edn New York: Springer. https://doi.org/10.1007/978-1-4614-1743-9

Pausas, J. G. (2015). Evolutionary fire ecology: Lessons learned from pines. Trends in Plant Science, 20, 318-324. https://doi.org/10.1016/ j.tplants.2015.03.001

Pausas, J. G., Alessio, G. A., Moreira, B., \& Corcobado, G. (2012). Fires enhance flammability in Ulex parviflorus. New Phytologist, 193, 18-23. https://doi.org/10.1111/j.1469-8137.2011.03945.x

Pausas, J. G., \& Keeley, J. E. (2009). A burning story: The role of fire in the history of life. BioScience, 59, 593-601. https://doi.org/10.1525/ bio.2009.59.7.10

Pausas, J. G., \& Keeley, J. E. (2014). Evolutionary ecology of resprouting and seeding in fire-prone ecosystems. New Phytologist, 204, 55-65. https://doi.org/10.1111/nph.12921

Pausas, J. G., Lamont, B. B., Paula, S., Appezzato-da-Gloria, B., \& Fidelis, A. (2018). Unearthing belowground bud banks in fire-prone ecosystems. New Phytologist, 217, 1435-1448. https://doi.org/10.1111/nph.14982

Pausas, J. G., Pratt, R. B., Keeley, J. E., Jacobsen, A. L., Ramirez, A. R., Vilagrosa, A., .. . Davis, S. D. (2016). Towards understanding resprouting at the global scale. New Phytologist, 209, 945-954. https://doi.org/10.1111/nph.13644

Pausas, J. G., \& Ribeiro, E. (2017). Fire and plant diversity at the global scale. Global Ecology and Biogeography, 26, 889-897. https://doi.org/ 10.1111 /geb.12596

Pole, M. S., \& Douglas, J. G. (1999). Bennettitales, Cycadales and Ginkgoales from the mid Cretaceous of the Eromanga Basin, Queensland, Australia. Cretaceous Research, 20, 523-538. https://doi.org/10.1006/ cres.1999.0164

Prentice, E., Knerr, N., Schmidt-Lebuhn, A. N., Gonzålez-Orozco, C. E., Bui, E. N., Laffan, S., \& Miller, J. T. (2017). Do soil and climate 
properties drive biogeography of the Australian proteaceae? Plant and Soil, 417, 317-329 https://doi.org/10.1007/s $11104-017-3261-6$

Rundel, P. W., Arroyo, M. T. K., Cowling, R. M., Keeley, J. E., Lamont, B. B., \& Vargas, P. (2016). Mediterranean biomes: Evolution of their vegetation, floras, and climate. Annual Review of Ecology, Evolution, and Systematics, 47, 383-407. https://doi.org/10.1146/annurev-ec olsys-121415-032330

Schwilk, D. W., \& Kerr, B. (2002). Genetic niche-hiking: An alternative explanation for the evolution of flammability. Oikos, 99, 431-442. https://doi.org/10.1034/j.1600-0706.2002.11730.x

Staniczenko, P. P. A., Sivasubramaniam, P., Suttle, K. B., \& Pearson, R. G. (2017). Linking macroecology and community ecology: Refining predictions of species distributions using biotic interaction networks. Ecology Letters, 20, 693-707. https://doi.org/10.1111/ele. 12770

Vandvik, V., T6pper, J. P., Cook, Z., Daws, M. I., Heegaard, E., Maren, I. E., \& Velle, L. G. (2014). Management-driven evolution in a domesticated ecosystem. Biology Letters, 10, 20131082. https://doi.org/10. $1098 / \mathrm{rsbl} .2013 .1082$

Verdü, M., \& Pausas, J. G. (2013). Syndrome-driven diversification in a mediterranean ecosystem. Evolution, 67, 1756-1766. https://doi.org/ 10.1111 /evo.12049

Verdü, M., Pausas, J. G., Segarra-Moragues, J. G., \& Ojeda, F. (2007). Burning phylogenies: Fire, molecular evolutionary rates, and diversification. Evolution, 61, 2195-2204. https://doi.org/10.1111/j.15585646.2007.00187.x

Vilagrosa, A., Hernăndez, E. I., Luis, V. C., Cochard, H., \& Pausas, J. G. (2014). Physiological differences explain the co-existence of different regeneration strategies in Mediterranean ecosystems. New Phytologist, 201, 1277-1288. https://doi.org/10.1111/nph.12584

Wade, M. J., \& McCauley, D. E. (1988). Extinction and recolonization: Their effects on the genetic differentiation of local populations. Evolution, 42, 995-1005. https://doi.org/10.1111/j.1558-5646.1988.tb 02518.x

Wells, P. V. (1969). The relation between mode of reproduction and extent of speciation in woody genera of the California chaparral. Evolution, 23, 264-267. https://doi.org/10.1111/j.1558-5646.1969. tb03510.x

Wisheu, I. C., Rosenzweig, M. L., Olsvig-Whittaker, L., \& Shmida, A. (2000). What makes nutrient-poor mediterranean heathlands so rich in plant diversity? Evolutionary Ecology Research, 2, 935-955.

\section{DATA AVAILABILITY}

The data used in this paper are available in the Supplementary Material and atwww.gbif.org.

\section{BIOSKE TC HES}

Juli G. Pausas is a research ecologist of the Spanish National Research Council (CSIC, Spain). His research focuses on the ecology and evolution of fire-prone ecosystems, and specifically on understanding the role of fire in shaping species, populations, communities, landscapes and biomes. For more information: http://www.uv.es/jgpausas/, @jgpausas

Byron B. Lamont studies fire-prone and drought-prone floras in an evolutionary context. He also has interests in plant nutrition, leaf and root structure, pollination, plant biogeography, species diversity of heathlands, adaptations to fire, drought, poor soils, granivores and herbivores, fire management and conservation biology. https://www.researchgate.net/profile/Byron_Lamont.

\section{SUPPOR TING INFORMATION}

Additional supporting information may be found online in the Supporting Information section at the end of the article. 


\title{
SUPPORTING INFORMATION
}

\section{Ecology and biogeography in 3D: the case of the Australian Proteaceae}

\author{
Juli G. Pausas \& Byron B. Lamont \\ doi: $10.1111 /$ jbi.13348
}

Table S1. All Proteaceae genera in Australia and any traits associated with nutrient-impoverished soils, seasonal drought, fire, and biotic and other agents of selection, together with their species richness and geographical location. Text in blue refers to universal or ancestral (dominant) trait for the genus. This table was produced from an extensive review of the literature (see main references below), internet sources, and from our own experience. Genera listed in the classification order given by Weston and Barker (2006). For a summary of this table see Fig. 1 of the main text.

\begin{tabular}{|c|c|c|c|c|c|c|}
\hline Genus* & Species & Location $^{+}$ & $\begin{array}{l}\text { Adaptations to poor } \\
\text { soils }^{\#}\end{array}$ & $\begin{array}{l}\text { Leaf adaptations to } \\
\text { drought }\end{array}$ & Adaptations to fire & $\begin{array}{l}\text { Biotic interactions, other } \\
\text { abiotic adaptations, }\end{array}$ \\
\hline Bellendena & 1 & Tas & proteoid roots & isobilateral, frost-resistant & $\begin{array}{l}\text { resprouting (rarely fire- } \\
\text { prone) }\end{array}$ & wind-dispersed, subshrub \\
\hline Placospermum & 1 & NEA & proteoid roots absent & $\begin{array}{l}\text { semi-erect, thick (adult), } \\
\text { pinnatisect (juvenile) }\end{array}$ & $\begin{array}{l}\text { fire-killed? (rarely fire- } \\
\text { prone) }\end{array}$ & wind-dispersed, rainforest tree \\
\hline Acidonia & 1 & SWA & long root hairs? & isolateral, erect, thick & $\begin{array}{l}\text { fire-killed, highly fecund, } \\
\text { fire-stimulated germination }\end{array}$ & emu-dispersed (drupes) \\
\hline Persoonia & 100 & $\begin{array}{l}\text { SWA, } \\
\text { NEA, EA, } \\
\text { SEA, Tas }\end{array}$ & long root hairs & $\begin{array}{l}\text { isolateral, thick, erect, thick } \\
\text { cuticles }\end{array}$ & $\begin{array}{l}\text { resprouting, fire-killed, } \\
\text { highly fecund, fire- } \\
\text { stimulated germination }\end{array}$ & bird-dispersed (drupes) \\
\hline Agastachys & 1 & Tas & proteoid roots absent & isobilateral, semi-erect, thick & $\begin{array}{l}\text { resprouting (rarely fire- } \\
\text { prone) }\end{array}$ & wind-dispersed \\
\hline Symphionema & 2 & NSW & dauciform-like roots & pinnatisect, nanophyllous & $\begin{array}{l}\text { resprouting, fire-killed, fire- } \\
\text { stimulated germination }\end{array}$ & subshrub \\
\hline Eidothea & 2 & NSW, Qld & proteoid roots & nil & $\begin{array}{l}\text { fire-killed? (rarely fire- } \\
\text { prone), forms resprouts in } \\
\text { absence of disturbance }\end{array}$ & $\begin{array}{l}\text { vertebrate dispersed (drupes), } \\
\text { rainforest tree }\end{array}$ \\
\hline
\end{tabular}


Pausas \& Lamont - 2

\begin{tabular}{|c|c|c|c|c|c|c|}
\hline Cenarrhenes & 1 & Tas & proteoid roots & nil & fire-killed (rarely fire-prone) & bird-dispersed (drupes) \\
\hline Franklandia & 2 & SWA & proteoid roots & $\begin{array}{l}\text { isolateral, acicular, erect, } \\
\text { thick, multidichotomous }\end{array}$ & $\begin{array}{l}\text { resprouting, fire-stimulated } \\
\text { germination, leaf litter } \\
\text { buildup }\end{array}$ & wind-dispersed \\
\hline Stirlingia & 7 & SWA & proteoid roots & $\begin{array}{l}\text { isolateral, acicular, erect, } \\
\text { thick, multidichotomous }\end{array}$ & $\begin{array}{l}\text { resprouting, fire-stimulated } \\
\text { germination, fire-killed, leaf } \\
\text { litter buildup }\end{array}$ & wind-dispersed \\
\hline Conospermum & 53 & $\begin{array}{l}\text { SWA, SEA, } \\
\text { Tas }\end{array}$ & proteoid roots & $\begin{array}{l}\text { isolateral, acicular, erect, } \\
\text { thick, pubescent }\end{array}$ & $\begin{array}{l}\text { resprouting, fire-stimulated } \\
\text { germination, fire-killed, leaf } \\
\text { litter buildup }\end{array}$ & wind-dispersed, subshrub \\
\hline Synaphea & $>50$ & SWA & proteoid roots & $\begin{array}{l}\text { isolateral, semi-erect, } \\
\text { reticulate veins, pinnatisect }\end{array}$ & $\begin{array}{l}\text { resprouting, fire-stimulated } \\
\text { germination, dead foliage } \\
\text { retention }\end{array}$ & wind-dispersed, subshrub \\
\hline Petrophile & 53 & $\begin{array}{l}\text { SWA, SEA, } \\
\text { EA }\end{array}$ & proteoid roots & $\begin{array}{l}\text { isolateral, acicular, } \\
\text { (semi)erect, thick, pinnatisect }\end{array}$ & $\begin{array}{l}\text { resprouting, fire-killed, fire- } \\
\text { stimulated seed release, dead } \\
\text { foliage retention (SWA), } \\
\text { postfire cryptic seeds }\end{array}$ & $\begin{array}{l}\text { wind-dispersed, subshrub, leaf } \\
\text { spinescence }\end{array}$ \\
\hline Isopogon & 35 & $\begin{array}{l}\text { SWA, SEA, } \\
\text { EA, Tas }\end{array}$ & proteoid roots & $\begin{array}{l}\text { isolateral, thick, acicular, } \\
\text { (semi)erect, pinnatisect }\end{array}$ & $\begin{array}{l}\text { resprouting, fire-killed, fire- } \\
\text { stimulated seed release, dead } \\
\text { foliage retention (SWA), } \\
\text { postfire cryptic seeds }\end{array}$ & $\begin{array}{l}\text { wind-dispersed, subshrub, leaf } \\
\text { spinescence }\end{array}$ \\
\hline Adenanthos & 35 & SWA & proteoid roots & $\begin{array}{l}\text { isolateral, thick, digitate, } \\
\text { semi-erect, pubescent, } \\
\text { serrated }\end{array}$ & $\begin{array}{l}\text { resprouting, fire-killed, fire- } \\
\text { stimulated germination, dead } \\
\text { foliage retention }\end{array}$ & $\begin{array}{l}\text { extrafloral nectaries, ant- } \\
\text { dispersed, bird pollination }\end{array}$ \\
\hline Sphalmium & 1 & NEA & proteoid roots & nil & $\begin{array}{l}\text { fire-killed? (rarely fire- } \\
\text { prone) }\end{array}$ & wind-dispersed, rainforest tree \\
\hline Carnarvonia & 1 & NEA & proteoid roots & nil & $\begin{array}{l}\text { fire-killed? (rarely fire- } \\
\text { prone) }\end{array}$ & $\begin{array}{l}\text { wind-dispersed, young leaves } \\
\text { red, rainforest tree }\end{array}$ \\
\hline Megahertzia & 1 & NEA & proteoid roots & nil & $\begin{array}{l}\text { fire-killed? (rarely fire- } \\
\text { prone) }\end{array}$ & wind-dispersed, rainforest tree \\
\hline Neorites & 1 & NEA & proteoid roots & nil & $\begin{array}{l}\text { fire-killed? (rarely fire- } \\
\text { prone) }\end{array}$ & wind-dispersed, rainforest tree \\
\hline Orites & 7 & $\begin{array}{l}\text { NSW, Qld, } \\
\text { Tas }\end{array}$ & proteoid roots & $\begin{array}{l}\text { ericoid (alpine), pinnatisect } \\
\text { (juvenile) }\end{array}$ & $\begin{array}{l}\text { resprouting (alpine), fire- } \\
\text { killed (rainforest) }\end{array}$ & $\begin{array}{l}\text { wind-dispersed, rainforest tree } \\
\text { or alpine shrub }\end{array}$ \\
\hline Lambertia & 10 & SWA, SEA & proteoid roots & microphyllous, semi-erect & resprouting, fire-killed, fire- & bird-pollinated, fruit crypsis, \\
\hline
\end{tabular}


Pausas \& Lamont - 3

\begin{tabular}{|c|c|c|c|c|c|c|}
\hline & & & & & stimulated seed release & wind-dispersed \\
\hline Xylomelum & 6 & SWA, SEA & $\begin{array}{l}\text { proteoid roots, seed } \\
\text { nutrient storage }\end{array}$ & microphyllous, semi-erect & $\begin{array}{l}\text { resprouting, fire-stimulated } \\
\text { seed release, postfire cryptic } \\
\text { seeds }\end{array}$ & wind-dispersed \\
\hline Helicia & 9 & $\begin{array}{l}\text { NEA, EA, } \\
\text { SEA, NNT }\end{array}$ & proteoid roots & nil & $\begin{array}{l}\text { fire-killed? (rarely fire- } \\
\text { prone) }\end{array}$ & rainforest tree \\
\hline Hollandaea & 4 & NEA & proteoid roots & (semi)erect & $\begin{array}{l}\text { fire-killed? (rarely fire- } \\
\text { prone) }\end{array}$ & $\begin{array}{l}\text { rainforest tree, young leaves } \\
\text { purple }\end{array}$ \\
\hline Darlingia & 2 & NEA & proteoid roots & $\begin{array}{l}\text { pinnatisect, abaxial vein } \\
\text { pubescence }\end{array}$ & $\begin{array}{l}\text { fire-killed? (rarely fire- } \\
\text { prone) }\end{array}$ & wind-dispersed, rainforest tree \\
\hline Floydia & 1 & NSW, Qld & $\begin{array}{l}\text { proteoid roots, seed } \\
\text { nutrient storage }\end{array}$ & nil & $\begin{array}{l}\text { fire-killed? (rarely fire- } \\
\text { prone) }\end{array}$ & hard pericarp, rainforest tree \\
\hline Musgravea & 2 & NEA & proteoid roots & nil & $\begin{array}{l}\text { fire-killed? (rarely fire- } \\
\text { prone) }\end{array}$ & wind-dispersed, rainforest tree \\
\hline Austromuellera & 2 & NEA & proteoid roots & nil & $\begin{array}{l}\text { fire-killed? (rarely fire- } \\
\text { prone) }\end{array}$ & wind-dispersed, rainforest tree \\
\hline Banksia ss & 78 & $\begin{array}{l}\text { SWA, } \\
\text { NEA, EA, } \\
\text { SEA, NA }\end{array}$ & $\begin{array}{l}\text { proteoid roots }(\mathrm{cpd}) \text {, } \\
\text { seed nutrient storage }\end{array}$ & $\begin{array}{l}\text { thick adaxial cuticle, crypts, } \\
\text { abaxial surface with hairs, } \\
\text { ericoid, serrated, (semi)erect, } \\
\text { prostrate habit with long- } \\
\text { lived leaves, water-retaining } \\
\text { testa }\end{array}$ & $\begin{array}{l}\text { resprouting, clonal, fire- } \\
\text { killed, fire-resistant follicles, } \\
\text { fire-stimulated seed release, } \\
\text { flammable dead floret and } \\
\text { foliage (SWA) retention, } \\
\text { postfire cryptic seeds }\end{array}$ & $\begin{array}{l}\text { bird/mammal-pollinated, } \\
\text { wind-dispersed }\end{array}$ \\
\hline Dryandra & 93 & SWA & $\begin{array}{l}\text { proteoid roots }(\mathrm{cpd}), \\
\text { seed nutrient storage }\end{array}$ & $\begin{array}{l}\text { thick adaxial cuticle, ericoid } \\
\text { (crypt), abaxial surface with } \\
\text { hairs, serrated, semi-erect, } \\
\text { prostrate habit, water- } \\
\text { retaining testa }\end{array}$ & $\begin{array}{l}\text { resprouting, fire-killed, fire- } \\
\text { resistant follicles, fire- } \\
\text { stimulated seed release, } \\
\text { flammable dead floret and } \\
\text { foliage retention, postfire } \\
\text { cryptic seeds }\end{array}$ & $\begin{array}{l}\text { bird/mammal-pollinated, } \\
\text { wind-dispersed }\end{array}$ \\
\hline Lomatia & 12 & $\begin{array}{l}\text { SEA, EA, } \\
\text { Tas }\end{array}$ & proteoid roots & highly pinnatisect, semi-erect & $\begin{array}{l}\text { resprouting or fire-killed } \\
\text { (eucalypt forest), or rarely } \\
\text { fire-prone (rainforest) }\end{array}$ & $\begin{array}{l}\text { bird-pollinated, wind- } \\
\text { dispersed }\end{array}$ \\
\hline Alloxylon & 3 & NEA, EA & proteoid roots & pinnate or pinnatisect & $\begin{array}{l}\text { fire-killed? (rarely fire- } \\
\text { prone) }\end{array}$ & $\begin{array}{l}\text { bird-pollinated, wind- } \\
\text { dispersed, rainforest tree }\end{array}$ \\
\hline Telopea & 5 & SEA, Tas & proteoid roots & semi-erect, serrated, thick & $\begin{array}{l}\text { resprouting or fire-killed } \\
\text { (eucalypt forest), or rarely }\end{array}$ & $\begin{array}{l}\text { bird-pollinated, wind- } \\
\text { dispersed }\end{array}$ \\
\hline
\end{tabular}


Pausas \& Lamont - 4

\begin{tabular}{|c|c|c|c|c|c|c|}
\hline & & & & & fire-prone (rainforest) & \\
\hline Stenocarpus & 10 & NA, EA & proteoid roots & $\begin{array}{l}\text { pinnate or pinnatisect, semi- } \\
\text { erect }\end{array}$ & $\begin{array}{l}\text { fire-killed? (rarely fire- } \\
\text { prone) }\end{array}$ & $\begin{array}{l}\text { bird-pollinated, wind- } \\
\text { dispersed, rainforest tree }\end{array}$ \\
\hline Strangea & 3 & SWA, EA & proteoid roots & $\begin{array}{l}\text { thick, pubescent, erect, } \\
\text { sublinear }\end{array}$ & $\begin{array}{l}\text { resprouting, fire-stimulated } \\
\text { seed release }\end{array}$ & wind-dispersed \\
\hline Opisthiolepis & 1 & NEA & proteoid roots & $\begin{array}{l}\text { pinnate (juvenile), abaxial } \\
\text { surface pubescent }\end{array}$ & $\begin{array}{l}\text { fire-killed? (rarely fire- } \\
\text { prone) }\end{array}$ & $\begin{array}{l}\text { bird-pollinated, wind- } \\
\text { dispersed, rainforest tree }\end{array}$ \\
\hline Buckinghamia & 2 & NEA & proteoid roots & pinnate (juvenile) & $\begin{array}{l}\text { fire-killed? (rarely fire- } \\
\text { prone) }\end{array}$ & wind-dispersed, rainforest tree \\
\hline Hakea & 154 & $\begin{array}{l}\text { SWA (100), } \\
\text { EA, NA, } \\
\text { CA, Tas }\end{array}$ & $\begin{array}{l}\text { proteoid roots, seed } \\
\text { nutrient storage } \\
\text { (prolonged seed } \\
\text { filling) }\end{array}$ & $\begin{array}{l}\text { thick, dense, vascular fibre } \\
\text { bands, (semi)erect, acicular, } \\
\text { thick cuticle, double } \\
\text { palisade, tanniniferous } \\
\text { hypodermis, crypts with } \\
\text { hairs, pubescence (young), } \\
\text { pinnatisect, prostrate habit, } \\
\text { water-retaining testa }\end{array}$ & $\begin{array}{l}\text { resprouting, clonal, fire- } \\
\text { killed, fire-resistant follicles, } \\
\text { fire-stimulated seed release, } \\
\text { dead foliage retention } \\
\text { (SWA), postfire cryptic seeds }\end{array}$ & $\begin{array}{l}\text { bird-pollinated - floral } \\
\text { cyanogens (antiherbivory), } \\
\text { leaf spinescence, fruit crypsis } \\
\text { via leaf mimicry, large woody } \\
\text { follicles (cockatoo } \\
\text { protection), wind dispersal }\end{array}$ \\
\hline Grevillea & 360 & $\begin{array}{l}\text { SWA }(250) \\
\text { EA, NA, } \\
\text { CA, Tas }\end{array}$ & $\begin{array}{l}\text { proteoid roots, seed } \\
\text { nutrient storage }\end{array}$ & $\begin{array}{l}\text { (highly) pinnatisect, pinnate, } \\
\text { linear, ericoid (crypts), } \\
\text { abaxial surface pubescent, } \\
\text { (semi)erect, prostrate habit, } \\
\text { water-retaining testa }\end{array}$ & $\begin{array}{l}\text { resprouting, clonal, fire- } \\
\text { killed, fire-stimulated } \\
\text { germination, leaf litter } \\
\text { buildup }\end{array}$ & $\begin{array}{l}\text { bird-pollinated - floral } \\
\text { cyanogens (antiherbivory), } \\
\text { ant-dispersed and/or wind- } \\
\text { dispersed, rainforest (rare) }\end{array}$ \\
\hline Macadamia & 4 & EA & $\begin{array}{l}\text { proteoid roots, seed } \\
\text { nutrient storage }\end{array}$ & serrated & $\begin{array}{l}\text { fire-killed? (rarely fire- } \\
\text { prone) }\end{array}$ & $\begin{array}{l}\text { frugivore-dispersed, hard } \\
\text { 'endocarp', rainforest tree }\end{array}$ \\
\hline Catalepidia & 1 & NEA & $\begin{array}{l}\text { proteoid roots, seed } \\
\text { nutrient storage }\end{array}$ & nil & $\begin{array}{l}\text { fire-killed? (rarely fire- } \\
\text { prone) }\end{array}$ & $\begin{array}{l}\text { frugivore-dispersed, hard } \\
\text { 'endocarp', rainforest tree }\end{array}$ \\
\hline Lasjia & 3 & NEA & $\begin{array}{l}\text { proteoid roots, seed } \\
\text { nutrient storage }\end{array}$ & nil & $\begin{array}{l}\text { fire-killed? (rarely fire- } \\
\text { prone) }\end{array}$ & $\begin{array}{l}\text { frugivore-dispersed, hard } \\
\text { 'endocarp', rainforest tree }\end{array}$ \\
\hline Athertonia & 1 & NEA & proteoid roots & pinnatisect & $\begin{array}{l}\text { fire-killed? (rarely fire- } \\
\text { prone) }\end{array}$ & $\begin{array}{l}\text { frugivore-dispersed, hard } \\
\text { 'endocarp', rainforest tree }\end{array}$ \\
\hline Cardwellia & 1 & NEA & proteoid roots & nil & $\begin{array}{l}\text { fire-killed? (rarely fire- } \\
\text { prone) }\end{array}$ & wind-dispersed, rainforest tree \\
\hline Bleasdalea & 2 & NEA & proteoid roots & nil & $\begin{array}{l}\text { fire-killed? (rarely fire- } \\
\text { prone) }\end{array}$ & $\begin{array}{l}\text { frugivore-dispersed, hard } \\
\text { 'endocarp', rainforest tree }\end{array}$ \\
\hline Hicksbeachia & 2 & NEA & proteoid roots & pinnatisect & fire-killed? Root-crown & frugivore-dispersed, hard \\
\hline
\end{tabular}




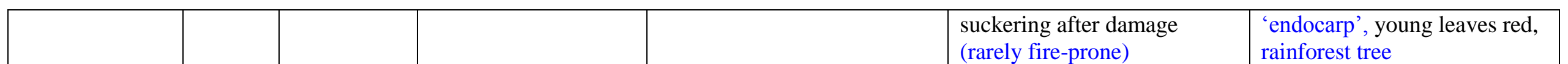

* Colours of the genus names: in red most species occur in sclerophyll vegetation; in green, most occur rainforest.

\# Seed nutrient storage not well documented (Groom and Lamont 2010). cpd = compound

${ }^{\wedge}$ thick $=$ depth $\geq 1 \mathrm{~mm}$. Note all isolateral leaves have sunken stomates and cuticle raised over them.

${ }^{+}$Location: $\mathrm{SW}=$ southwestern, $\mathrm{A}=$ Australia, NE = northeastern, Tas = Tasmania, E = eastern, NSW = New South Wales, Qld = Queensland, NNT = northern Northern Territory.

\section{References}

Australia's Virtual Herbarium. Proteaceae records. https://avh.chah.org.au, accessed 17 May2017.

Cowling, R.M. and Lamont, B.B. 1998. On the nature of Gondwanan species flocks: diversity of Proteaceae in mediterranean Australia and South Africa. Australian Journal of Botany 46, 335-355.

Groom, P.G. and Lamont, B.B. 2015. Plant Life of Southwestern Australia: Adaptations for Survival. De Gruyter Open, Warsaw, Poland.

Groom, PK and Lamont, BB 2010. Phosphorus accumulation in Proteaceae seeds: a synthesis. Plant \& Soil 334, 61-72.

He T, Lamont BB, Downes KS. 2011. Banksia born to burn. New Phytologist 191, 184-196.

Hanley, ME, Lamont, BB and Armbruster, SW 2009. Pollination and plant-defence traits co-vary in Western Australian Hakeas. New Phytologist 182, 251-60.

Lamont, B.B. 1993. Nutrient/water relations, reproductive biology and population dynamics of the south-western Australian flora, with particular reference to the Proteaceae. Doctor of Science thesis, University of Western Australia.

Lamont, B.B. and Groom, P.K. 1998. Seed and seedling biology of the woody-fruited Proteaceae. Australian Journal of Botany 46, $387-406$.

Lamont, B.B., Groom, P.K., Williams, M and He, T. 2015. LMA, density and thickness: recognizing different leaf shapes and correcting for their non-laminarity. New Phytologist 207:942-947.

Lamont, B.B., Le Maitre, D., Cowling, R.M. and Enright, N.J. 1991. Canopy seed storage in woody plants. The Botanical Review 57, $277-317$.

Lamont, BB and He, T. 2012. Fire-adapted Gondwanan Angiosperm floras arose in the Cretaceous. BMC Evolutionary Biology 12: 223.

Lamont, BB, Hanley ME, Groom, PK and He, T 2016. Bird pollinators, seed storage and cockatoo granivores explain large woody fruits as best seed defense in Hakea. Perspectives in Plant Ecology, Evolution and Systematics. 21, 55-77.

Lamont, BB, He, T and Lim, SL 2016. Hakea, the most world's most sclerophyllous genus, arose in southwest Australian heathland and diversified throughout Australia over the last 12 million years. Australian Journal of Botany 64, 77-88.

Myerscough, P. J., Whelan, R. J., \& Bradstock, R. A. (2000). Ecology of Proteaceae with special reference to the Sydney region. Cunninghamia, 6, 951-1015.

Rossetto, M., \& Kooyman, R. M. (2005). The tension between dispersal and persistence regulates the current distribution of rare palaeo-endemic rain forest flora: a case study. Journal of Ecology, 93(5), 906-917. 
Pausas \& Lamont - 6

Weston, P. H., \& Barker, N. P. (2006). A new suprageneric classification of the Proteaceae, with an annotated checklist of genera. Telopea, 11(3), 314-344. 